Noémi LŐRINCZ

\title{
MAIN CHARACTERISTICS OF NOWADAYS' GLOBAL VALUE CHAINS AND THEIR RELEVANCE TO THE HUNGARIAN AUTOMOTIVE MANUFACTURING INDUSTRY
}

Modern-day globalization allows international fragmentation and production sharing. By connecting companies, employees and consumers, global value chains (GVCs) influence the structure of international trade with effects on countries' GDP, employment and ultimately on the global economy. Enterprises have the opportunity to enter and to upgrade their position within GVCs leading to higher integration in global trade. However, participating in GVCs also has a complex set of prerequisites, including the need to invest in infrastructure, institutions, services, labor force, and in general trade and business environment. We can also name specific characteristics, which enable economies to reinforce their activity within GVCs, like cheap labor force, proximity to end markets or signed trade agreements. For many developing countries this integration process is a major lever of intensive development.

This paper analyzes the role of Hungary in global value chains with a focus on the automotive manufacturing industry. It overviews global and local changes occurred in the last decades, when foreign direct investments of automotive manufacturers appeared in the country. The findings of the article could be of great assistance for policy makers to answer questions about the possible development paths and can provide some ideas about actions needed for an effective, beneficial participation in GVCs.

Key words: global value chains, automotive manufacturing, value added, competitiveness, workforce development

In today's global economy there is a systematic shift observable from the traditional multinational enterprise model to a more dynamic one, where ownership and control are separate. It is the result of a growing pressure for cost efficiency, organizational flexibility and agility to attain resources and to reach consumers at different markets (Beleska-Spasova, 2016).

Regarding manufacturing activities, since the 1990 s there is a significant relocation tendency from the developed to the developing countries (Baldwin et al., 2014). With opening to new and higher value added markets, global value chain (GVC) participation offers - especially for developing countries - several technological innovations and the ability to add more value within industrial production, to improve labor force demand and productivity, and to raise income consequently. Governance of GVCs and upgrading within or between them can improve development and competitiveness of economies (Bamber et al.,
2013). However, the improvement of own capabilities is a complex prerequisite to capture this opportunity to foster structural economic growth. The global value chain analysis comprises the effects of these new patterns of international trade and production (Gereffi, 2016).

The purpose of this paper is to reveal how the integration and the upgrading of the automotive manufacturing companies within GVCs affect the Hungarian economy. Albeit the topic of GVCs is widely discussed in the international literature, there is a gap relating the Hungarian automotive manufacturing industry. This article discusses the following subtopics based on an expansive literature review:

- role of the automotive manufacturers in Hungary's GVC participation,

- the amount of value added part in the production (export-import), 
- spillover effects of foreign multinationals on the skills of labor force, on managerial and organizational methods and on the Hungarian economy overall, including growth, infrastructure, wages, etc.

The first main part of the paper gives a comprehensive theoretical background of the GVCs, including their key characteristics, functions, different types and upgrading possibilities. After introducing the GVC framework, the paper describes the development of the foreign direct investment (FDI) inflow into Hungary from the 1990s, focusing on the automotive manufacturing industry and its connection to the GVCs. It also presents the main features and the key players of the automotive manufacturing sector in the country. The final, concluding part is a summary of the literature research including some predictions about the future trends of the automotive manufacturing industry in general and its relations to Hungary.

\section{Global value chains (GVCs)}

Recent years' trade liberalization and investment arrangements have facilitated the growth of GVCs, which served as a key pillar for the interconnectedness of economies. The roots of the GVC concept can be derived from the global commodity chain approach from Gary Gereffi et al. (1994). It refers to an international character of value flows, where multiple nations bring their goods or services through the different phases of production and deliver them to final consumers and final disposal after use (Gereffi, 2005). It is described as an interorganizational network around one product, which connects households, enterprises and states. The network is embedded in the world-economy (Gereffi et al., 1994). Due to advanced information technologies, transport, trade and business innovation of the 21st century, GVCs attained a central role in today's global economy.

A final product's global value chain comprises the value added of all activities that are directly and indirectly necessary for its production (Timmer et al., 2014). A value chain is a collection of business activities at the firm level, like actual manufacturing of products or creation of services, delivery, marketing, after sales services, etc. To ensure competitive advantage after the aggregation of all of the above-mentioned discrete activities, firms either have relative lower cost structure compared to their competitors or differentiate their products. According to Porter, because of the high relevance of international competition, companies need to adopt their global strategies by expanding activities in the value chain among countries (Gereffi, 2005). Global value chains take various forms: they are either short or long, with limited or numerous discrete stages in production, consumption and trade. To perform its tasks, the lead firm can opt for in-house solutions or outsourcing (Low, 2016). In case of outsourcing, when a product is completed in a particular country, it does not mean that the domestic companies lead and govern the value chain, e.g. Apple governs the production network of its products and they are completed in Asia (Timmer et al., 2014).

There are three major characteristics of the current stage of globalization: larger share of intermediate inputs in total trade, development of global production networks and presence of production processes around the world (Gereffi, 2005). There is a strong correlation between FDI stocks and the GVC participation index of both the developed and developing countries (OECD, 2014). Developing countries with their low cost labor force and raw materials and developed countries with their R\&D and design capabilities affect each other even in widely separated locations (Gereffi - Fernandez-Stark, 2016).

Stages of manufacturing are dispersed over the world and they are often owned or controlled by independent suppliers. A significant amount of these international supply chains is regional and not global (Baldwin, 2009). (GVCs are still in majority, but regional chains are having growing importance nowadays in value chains research (Staritz et al., 2011).) Generally, a tendency of growing specialization is observable, where specific activities and stages in value chains are in focus rather than entire industries. In GVCs not all firms and countries are equally involved. The connectedness of economies is influenced by many different factors, some with fix considerations (e.g. location, resources, etc.) and some by public policy-shaped ones (e.g. infrastructure, investment climate, human capital, etc.). Policy makers of various countries can influence the extent of the involvement of the firms in GVCs significantly, e.g. with attracting investments or with influencing competitiveness (OECD, 2014). Today's GVCs are still dominated by the multinational enterprises of advanced economies, like companies from the USA, Japan or Germany (Alvstam et al., 2016).

Organizations have to face constantly accelerating changes in the macro-, industrial- and micro environment, which requires them to become more dynamic and to adapt faster to the turbulent and complex environment (Balaton et al., 2014; Balaton - Tari, 2014). Quality and efficiency of developed logistics services and international regulatory cooperation are essential in GVC participation, e.g. in the case of trade it is important to avoid unnecessary delays, to cut costs and to reduce uncertainty. Successful integration into GVCs has numerous positive effects on the trade, growth, 
labor market and general economic development of countries (OECD, 2014), because participating companies have access to new technologies and know-how, which results in improved productivity. Furthermore, GVCs can provide access to global markets and to acquisition possibilities of technological and managerial knowledge. At the same time, they may affect the operations of other companies negatively by limiting their participation or excluding them from GVCs (Contreras et al., 2010). Realizing the gains mentioned are not automatic and participation in GVCs does not guarantee stimulated growth: governance frameworks, effective social and environmental policies are essential to maximize the benefits of GVC participation. Structural policies and macroeconomic measures should also facilitate the growth process, where the local conditions of each country are different. Minimizing risks in countries is also important, especially in developing countries (OECD, 2014). Developing countries have to deal with a higher competitive pressure during their integration into global markets, where producers have two choices: either to increase the skills and competence of their activities and those of their workers or to move to other niche markets, where entry barriers reduce the intensity of competition (Humphrey - Schmitz, 2002).

GVCs require skilled labor force, thereby affecting also the structure and quality of the labor market in the involved countries. Nowadays, there is a strong international competition between workers, which formerly used to be on the level of companies and industries in different nations. Individual tasks are able to be offshored, which is very helpful for some workers, but can be harmful for others (Baldwin, 2006).

GVCs mostly consist of differently developed private firms from small and medium enterprises (SMEs) to multinational enterprises (MNEs), with different places in the GVC hierarchy, usually with different industry background and organizational characteristics. Value chains are coordinated by large MNEs in general, who cover the highest-value activities and they define the participating conditions for other firms, including the upgrading opportunities for them (OECD, 2014). Typical GVC entry for SMEs is selling goods and services to larger MNEs. According to OECD, 80$90 \%$ of the total employment in developing countries is employed by companies in GVCs, therefore, it is reasonable to stimulate the participation of such firms in GVCs. SME development policies, supplier-development programs can directly contribute to the cooperation with foreign firms. However, SMEs also face certain barriers set by the governments or by foreign firms; furthermore, they have to be able to comply with different international standards. Several less developed countries and SMEs failed to meet the require- ments of high-income markets (Staritz et al., 2011). Barriers for domestic companies are usually caused by defects or weaknesses in the financial market, infrastructure, human capital or in the local industry. It is important to emphasize that the potential advantages realizable from participating in GVCs depend not only on the chains where SMEs operate, but also on the local circumstances of a country. Business environment and institutions influence local firms' ability to increase their productivity and to upgrade to a higher value added activity within GVCs (OECD, 2014). Then again, governments play a crucial role in the regulation of firm capabilities with a huge impact on competitiveness and on general investment attractiveness. Educational institutions are important as well, because they are responsible for the human capital development. Investment- and development encouraging policies - focusing on local suppliers - are also crucial in accessing the GVCs and in the upgrading of developing economies. According to a questionnaire conducted by the OECD and the WTO in 2013, developing economies point out three main obstacles their firms have to deal with by connecting value chains: infrastructure problems, financial market accessibility problems and standard compliance problems (OECD, 2014).

GVC participation of the economies are determined mostly by geographical factors and by the countries' policy in the medium term. In general, the most important factors are size of the domestic market, income per capita, share of manufacturing sector, and the country's distance to manufacturing hubs (OECD, 2014). According to Bamber et al. (2013), in the case of developing countries there are five factors, which influence the competitiveness of the GVC participating countries: productive capacity, infrastructure and services, business environment, trade and investment policy and industry institutionalization. They significantly differ among specific industry contexts (Bamber et al., 2013).

\section{Types of GVCs}

The literature distinguishes between goods and services value chains. There are certain differences in the way they function, but globalization affects both similarly, e.g. service-related tasks are also increasingly outsourced. The development of value chains in goods also needs services (e.g. IT, telecommunication, logistics, R\&D, etc.) (WEF, 2012). In case of a services value chain, the activity of a company can be a core- or an outsourced competence (mostly back-office activities). The aim of these services is to be higher value added through innovation, design, R\&D or branding development. Banking, tourism, health and IT ser- 
vices are the most typical among services value chains (WEF, 2012). Based on the governance, we also distinguish between buyer- and producer-driven chains. In the case of a buyer-driven chain, large retailers and merchandisers have powerful roles (e.g. Tesco, Nike). In producer-driven chains technological and scale advantages are in the focus and vertically integration is typical to the segments of the supply chain (Gereffi Fernandez-Stark, 2016).

\section{Types of upgrading within and between GVCs}

Global competition force enterprises to upgrade their activities and to bring higher value added products and services constantly to the market (Gereffi, 2005). Changes of the last decades occurred in the global business organizations have had significant impact also on the upgrading possibilities of developing countries (Gereffi, 2005). According to Humphrey and Schmitz (2002), upgrading process of the activities of firms can materialize in four different ways:

- Functional upgrading: moving to higher value functions. A company acquires new capabilities, which are higher value added and therefore competitive products and services can be offered in new segments of a GVC (Humphrey - Schmitz, 2002; OECD, 2014; Fernandez-Stark et al., 2011). According to the range of its new functions, the position of the firm also increases (Staritz et al., 2011).

- Process upgrading: using more sophisticated technologies and methods in the production. A company acquires new capabilities, which are more efficient than the one of its rivals. Capital investment and better skills of workers are needed to use the new technologies, but costs can be reduced and flexibility can be improved. It can result in more complex services and lower defect rate (Humphrey - Schmitz, 2002; OECD, 2014; Fernandez-Stark et al., 2011). Process upgrading can also occur by re-organization of the production system and not only by the introduction of new technologies (Staritz et al., 2011).

- Product upgrading: producing higher-value products. A company acquires capabilities resulting in better end-product quality, more value added and sophisticated product lines and faster new product releasing capabilities. By getting experienced in the industry, a company can move to higher value added commodities with higher returns (Humphrey - Schmitz, 2002; OECD, 2014; Fernandez-Stark et al., 2011). Upgraded products also have a higher unit value and price (Staritz et al., 2011).
- Chain upgrading: a company acquires capabilities to be able to participate in a new global value chain and to produce higher value added products or services (Humphrey - Schmitz, 2002; OECD, 2014; Fernandez-Stark et al., 2011). One chain's acquired capabilities can lead to competitive advantage in other chains (Staritz et al., 2011).

Further upgrading possibilities by Gereffi and Fernandez-Stark:

- Backward linkages upgrading: a local company supplies products or services to foreign companies, which are located in the country and are already members of a separate GVC (Gereffi - Fernandez-Stark, 2016).

- End-market upgrading: a company moves into larger or more sophisticated markets, which require production on larger scale and stability of prices or standardization (Gereffi - Fernandez-Stark, 2016).

It is important to emphasize that product and process upgrading can encourage growth in industries (Fernandez-Stark et al., 2011), and the way of upgrading is influenced by different types of industries and business environments (e.g. input-output structure of value chains, institutional context, etc.) (Gereffi - Fernandez-Stark, 2016). The possibilities of upgrading differ in each type of chains as well, because of the varying core competences of lead firms. Lead firms' strategies can support or enable the upgrading process, but in general they are supportive in the product and process upgrading (Staritz et al., 2011). The structure of a value chain is also influenced by the lead firm, who governs the whole chain. The allocation of resources and the relationships among the different participants within the value chain are determined by the governance structure (Staritz et al., 2011).

In developing countries the upgrading process can often fail because of qualified workforce shortages, including lack of sufficient management and supervisor quality. Differences in culture and languages can also limit the transfer of capabilities (Fernandez-Stark et al., 2011). In the production sector the private sector has a highlighted role in labor force development, e.g. some companies have internal trainings for their employees at entry. International institutions can support the upgrading process, e.g. the cooperation between ILO and the World Bank helps raising the labor standards of global supply chains ("Better Work program") and also global buyers have influence on improving working conditions and workforce development practices (Fernandez-Stark et al., 2011). 
Stakeholders of the value chains are companies, employees, educational institutions, government agencies, etc. Their relationships and roles influence the operation of value chains significantly. The upgrading process and the growth strategy of industries depend greatly on the stakeholders, therefore key players of the value chain should be identified first and foremost (Gereffi, 2016). In order to be able to enter GVCs or to upgrade within them, policies can help companies in the innovation and cost lowering processes in two different ways: in the case of a horizontal policy the different effects are economy-wide e.g. stable political and economic environment, developed labor market and infrastructure, etc. (WEF, 2012). The other case, the sector-specific policy can be harmful for the international competition. Beside policies and governmental measures, also innovative firms can help in supporting the upgrading process (OECD, 2014).

As Figure 1. the so called "Smile curve" shows, developed countries concentrate on high value added activities like R\&D, design, marketing and services, while developing countries focus on the lower value added ones, like production (Gereffi - Fernandez-Stark, 2016). The curve describes that the value added activities in manufacturing are in the pre- and post-fabrication services. The pre-fabrication services cover R\&D and design activities, while marketing and other services count as post-fabric activities. Both preand post-fabrication are carried out by developed countries, while the production activities mostly by the developing countries. The curve is introduced originally by founder and CEO of Acer, Stan Shih in the 1990s in the information technology-related manufacturing industry (Baldwin et al, 2014).

Also Francois and Wörz (2007) analyzed the linkages between services and manufacturing, and made some observations in this regard, including the following:

- with the level of development, also the importance of services in production is rising,

- linkages of services to manufacturing have become important in the 1990s.

As mentioned, countries which would like to participate in GVCs have to invest in R\&D, innovation, organizational know-how and branding. As a consequence, GVC-participating countries have higher skill levels. It is characteristic to most of the OECD countries that the share of high-skilled workers in manufacturing increased faster than that of low-skilled workers. For developing countries moving up into mid-value segment means focusing on technical education, while moving further into high-value segment requires development of managerial tasks (OECD, 2014). Beside the econom- ic dimensions of upgrading, the social upgrading is also very important, which makes the whole upgrading process more complex. An upgrading in social conditions means better working conditions with skilled workforce and improved salaries. Both types of upgrading are usual, they often happen parallel (Staritz et al., 2011).

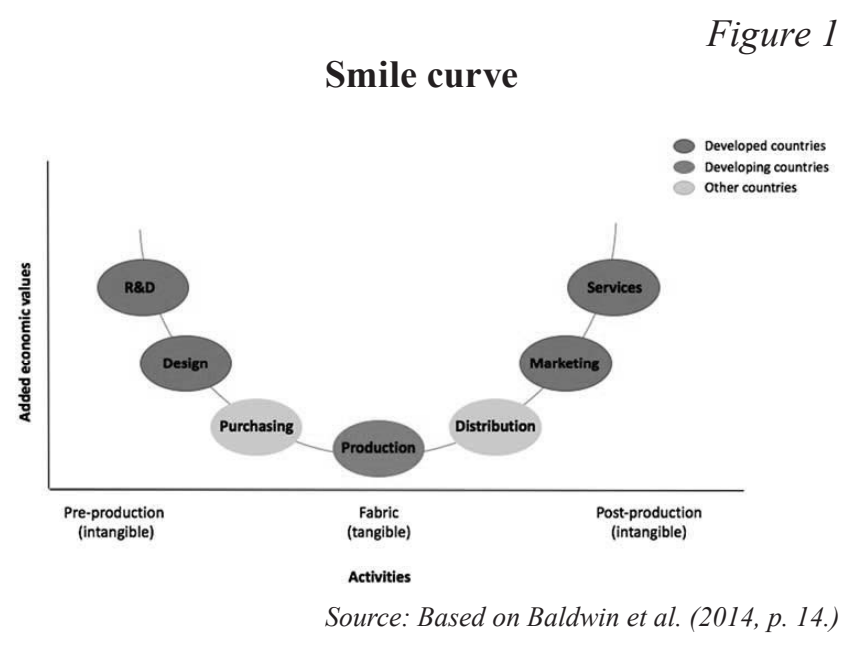

\section{Types of jobs relating to GVCs}

Changes in production locations have resulted in re-structurings also in specialization patterns. Gereffi and Fernandez-Stark (2016) differentiate five types of work in GVCs:

a) Informal small-, micro-enterprise and household work: these types are usual primarily for developing countries and for industries like agriculture or apparel industry. In general, they are low-paid jobs with low level of education. The production utilizes both the paid and unpaid family labor with long working hours (Gereffi - Fernandez-Stark, 2016).

b) Low-skilled, labor-intensive work: the working relationship between the employer and the worker can be temporary or permanent. Workers' education is low, maximized in six years in general. In global value chains the access to such lowcost and labor-intensive workforce was the main driver of offshoring activities (Gereffi - Fernandez-Stark, 2016).

c) Moderate-skilled work: in this stage of employment, specific technical knowledge is required and the level of education is higher. It is characteristic of the technology-intensive supply chains (Gereffi - Fernandez-Stark, 2016).

d) High-skilled, technology-intensive work: off-shoring of this type of work was especially 
typical in the 1980s and 1990s, in capital- and technology-intensive industries (e.g. automobile, electronics). However, it presents only a small share of GVC employment. Education level (technical) and wages are relative high (Gereffi Fernandez-Stark, 2016).

e) Knowledge-intensive work: businesses activities like IT, medical, finance and engineering services count as knowledge-intensive services. Due to the knowledge spillover into developing countries, these kind of business activities have significant growth potentials. High level of education and income are characteristic of workers in this category and their share in GVC employment is rather small (Gereffi - Fernandez-Stark, 2016)

Figure 2

Workforce allocation within different industries
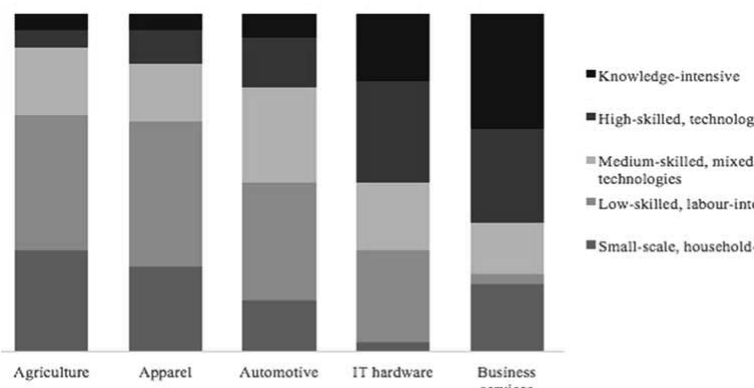

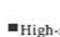
"Medium-skilled, mixed production

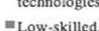
- Small-scale, household-based Source: Based on Gereffi-Fernandez-Stark (2016, p. 24.)

As Figure 2 shows, there is a general observation that to high-wage service jobs belong activities like $R \& D$ and marketing, while low-wage jobs are typical in production services (e.g. iPhones are designed in California and produced in China) (Baldwin et al., 2014).

\section{FDI as a driver of growth}

FDI is considered as the most important channel of international technological diffusion between countries. Multinational companies with advanced managerial techniques invest heavily in $R \& D$ and transfer their technologies and practices through FDI to foreign economies, which can spread later on over the entire economy (ECB, 2009). According to OECD studies, the GDP per capita growth rates of developing countries taking part in GVCs are $2 \%$ above average. These benefits are attainable mainly for countries with large domestic markets and local knowledge capacities, while economies with lower income or far from the international markets are less likely to benefit (OECD,
2014). The applied technologies and technical knowhow of multinational companies spread into local economies through suppliers' connection or movement of workers from multinational to national companies. Spillover from the applied know-how does not happen automatically, it depends significantly on the "sender" affiliates and on the "receiver" parties as well (OECD/ WTO, 2011; Contreras et al., 2010). Local companies not always have the accurate capabilities to take over the advanced technologies or techniques from foreign firms (Blomström - Kokko, 2003). Technology transfer between countries requires the receiving ability of the host country, due to the specificity of the technological knowledge. Human capital and productivity are not the only factors of knowledge absorptive capacity, the innovation effort of companies is also very important to establish the appropriate business environment (ECB, 2009). Technologies are getting more complex and it becomes more difficult to adopt them (Aghion et al., 2005). The spillover effect is influenced by the country, the sector, the type of the firms paired with the nature of the FDI and the domestic companies' absorptive capacities. Spillovers are more likely, when foreign affiliates and local companies are in direct competition with each other (ECB, 2009). The increased competition caused by foreigners' entry can stimulate locals to invest in new technologies and to work more effectively, which can be attractive for further foreign investors (Blomström - Kokko, 2003). Technology imports by MNCs are larger where educational level is higher, local competition is tougher and operational requirements are fewer (Blomström - Kokko, 2003). Even without any knowledge spillovers, the pure presence of MNCs can be beneficial for recipient countries, because MNCs are among the technologically most advanced enterprises (ECB, 2009).

\section{GVC participation of the Visegrad 4 countries}

In case of the Visegrad 4 countries (Czech Republic, Hungary, Poland and Slovakia) we can observe an increasing GVC participation and integration since 1995. Not just the import volume of component parts of manufacturing industries, but also their production contribution to GVCs has increased steadily. Even though countries showed up some common features, differences were observable, e.g. the integration level into GVCs varied. In terms of imports and exports Hungary is the more dependent on GVC participation, while Poland is to a lesser extent. Czech Republic, Hungary and Slovakia have relative comparative advantage in capital-intensive and high-tech industries, while Poland has resource-based industries predominantly (Grodzicky, 2014). The index of the economic openness (sum of exports and imports 
in \% of GDP) shows that Hungary and Slovakia had the most significant international trade since 1990, but there is an observable increase in Poland and in the Czech Republic as well (Grodzicky, 2014). A further sign of the economic integration is the increasing presence of multinational companies within these countries' production structures. In 2008 MNCs employed nearly a quarter of all labor force and produced $30-50 \%$ of the domestic products of the countries involved. Because of capital accumulation, structural transformation and knowledge diffusion the presence of multinationals and the international trade have positive effects on the development of these countries. The role of the EU was also important in the region's integration process within the global economy (Grodzicky, 2014). Based on different case-studies, an ongoing industrial upgrading process is observable in the Visegrad countries: besides of assembly operations at the early stages of the involvement, more and more complex tasks are being performed in the region. Recently, Hungary and the Czech Republic have the highest share of manufacturing in GVC income (ca. 60\%) (Grodzicky, 2014).

Table 1

EU countries with highest industrial growth index, 2011-15 (2010=100\%)

\begin{tabular}{|lrrrrr|}
\hline EU countries & $\mathbf{2 0 1 1}$ & $\mathbf{2 0 1 2}$ & $\mathbf{2 0 1 3}$ & $\mathbf{2 0 1 4}$ & $\mathbf{2 0 1 5}$ \\
\hline Slovakia & 105.2 & 113.6 & 117.9 & 128.1 & 137.0 \\
Ireland & 99.6 & 98.1 & 95.9 & 116.0 & 136.4 \\
Romania & 109.1 & 111.9 & 120.2 & 127.8 & 131.6 \\
Estonia & 119.4 & 121.2 & 126.3 & 131.7 & 128.6 \\
Hungary & 105.6 & $\mathbf{1 0 4 . 2}$ & $\mathbf{1 0 5 . 7}$ & $\mathbf{1 1 3 . 3}$ & $\mathbf{1 2 1 . 5}$ \\
Lithuania & 106.6 & 110.6 & 114.2 & 114.5 & 119.7 \\
Poland & 106.8 & 108.1 & 110.9 & 114.5 & 119.6 \\
Latvia & 108.9 & 115.8 & 115.0 & 114.0 & 118.1 \\
Czech Republic & 105.7 & 104.8 & 105.0 & 110.2 & 115.2 \\
Austria & 106.8 & 106.5 & 107.4 & 108.4 & 110.4 \\
Bulgaria & 105.9 & 105.5 & 105.3 & 107.2 & 110.3 \\
\hline
\end{tabular}

Based on the Hungarian Central Statistical Office (KSH) data, in 2015 the Hungarian industrial growth was $21.5 \%$ compared to the basis year of 2010 (Table 1). (There was a slowdown observable in 2012 and 2013.) Among the Visegrad 4 countries only Slovakia had a better growth performance in this period with $37 \%$. In the case of Hungary the automotive industry has a presumably outstanding role in this achievement (KSH, 2016b).

\section{The automotive industry and its connections to GVCs}

The automotive industry belongs to those sectors where large suppliers manage complex global production activities and have a significant impact on logistics, finance, design and product development process- es (Staritz et al., 2011). It is a very concentrated sector with a small number of large assembly firms with worldwide recognition and globalized suppliers (Humphrey - Memedovic, 2003; Contreras et al., 2010). For local suppliers of the sector the increased globalization meant a great opportunity to join global value chains. Relocation of manufacturers resulted in connections with local suppliers who could gain from the potential spillover effects, e.g. improving quality and speed of production processes. Furthermore, in case suppliers prepare themselves for the potential spillover effects, it is more likely that knowledge will be transferred by the satisfied value chain leaders to such companies (Contreras et al., 2010).

Globally, there are only a few large design centers (e.g. Detroit, Stuttgart, Tokyo) of automotive development, which implies that automotive industry's local, national and regional value chains are embedded within global organizational structures (Cattaneo et al., 2010). Due to a set of unique circumstances (technologies, governance policies, etc.), upgrading in the automotive industry is different from other upgrading processes. The most important factors are the engineer- and designer skills, the costs and workforce availability (Contreras et al., 2010). The upgrading is connected to public commitments, which support the FDI and innovation among companies (Bamber et al., 2013). In general, with the spread of different automation technologies a functional upgrading process is observable from labor-intensive to capital-intensive processes within the industry (Contreras et al., 2010).

\section{Value upgrading in the Hungarian automotive manufacturing sector}

During an industrial upgrading process, economic actors (countries, companies, workers) in global production networks move from low-value to high-value activities. In economic performance, the role of institutions, governments, corporate strategies, technologies and skills of workers are also determinative (Gereffi, 2005).

CEE countries went through a systematic transformation process during the 1990s (Balaton, 2005). In the first half of the ' 90 s relatively a large volume of FDI arrived in Hungary. Privatization was applied by the Hungarian government and as a result foreign investors attained a significant role in the ownership structure of enterprises by the end of the century (Balaton, 2011). Economic conditions became similar to Western European countries and firms were able to compete with firms in developed markets (Balaton, 2005). In these years foreign investors also appeared from the automotive industry in Hungary. Coupled with them, 
high-technology, modern business management and organization methods have come into the region, which have contributed to the successful change of industrial structure (KSH, 2011).

\section{Number of employees in the processing industry, 2015}

Figure 3

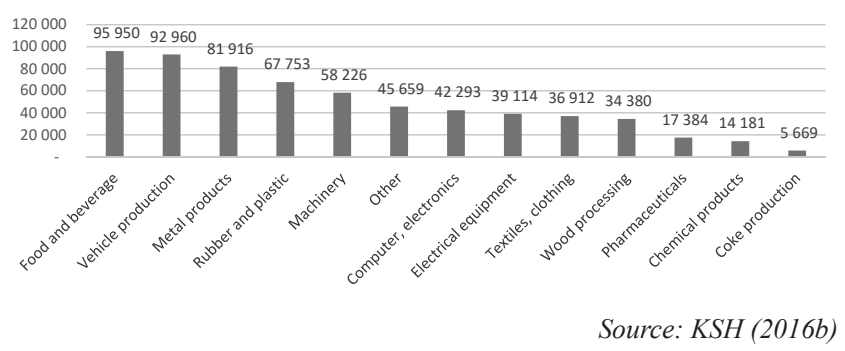

Nowadays, a significant amount of the Hungarian manufacturing resources is concentrated in the automotive industry (in Figure 3 the vehicle production has the second highest share of employment in the processing industry) (KSH, 2016b), which counts as one of the fastest growing sectors (PWC, 2014a) and plays a significant role in the country's economy. The Hungarian automotive industry is based on the presence of the OEMs (Original Equipment Manufacturers). They have originally appeared in the country as major greenfield investments, like Audi Hungaria Motor Kft. in Györ, Mercedes Benz Manufacturing Ltd. in Kecskemét, Opel Szentgotthárd Automotive Ltd. in Szentgotthárd and Magyar Suzuki Corporation in Esztergom (PWC, 2014a). The presence of the four major corporations have encouraged a significant number of suppliers to establish production capacities in the country, which resulted in an automotive industry which today consists of more than 700 companies. Many of the top TIER 1 suppliers have opened their operation in the country, like Bosch, Bridgestone, Continental, Delphi, Hankook Tires, Michelin, etc. (PWC, 2014a).

And why do car manufacturers like Hungary? First of all, the territorial proximity to investors' current major markets (Western Europe) and the relatively cheap and skilled labor force are necessary for global manufacturers to assemble vehicles in the CEE region (Havas, 1997). Furthermore, in investment decisions tax incentives also play a crucial role and CEE countries have offered favorable grants and tax holidays for foreign investors (Havas, 1997).

Because of constant demand for products with high technological solutions, the innovation potential of the automotive business is high. It requires high capital investment, since the production of components and the final assembly works are built on high-tech machinery and equipment paired with skilled workforce (KSH, 2011). Nowadays, ca. $65 \%$ of cars and car parts produced in CEE plants are exported to Western Europe, and $17 \%$ of car production in Greater Europe comes from CEE factories (grew from a low level of 7\% in 2000) (McKinsey Global Institute, 2013). As Figure 4 shows, labor costs in CEE are far below the Western and Southern European levels and this significant difference has increased since the crisis (Eurostat, 2017). Within CEE, Hungary is among the countries with the cheapest labor costs.

\section{Labor costs in the EU-28 countries (EUR)}

Figure 4

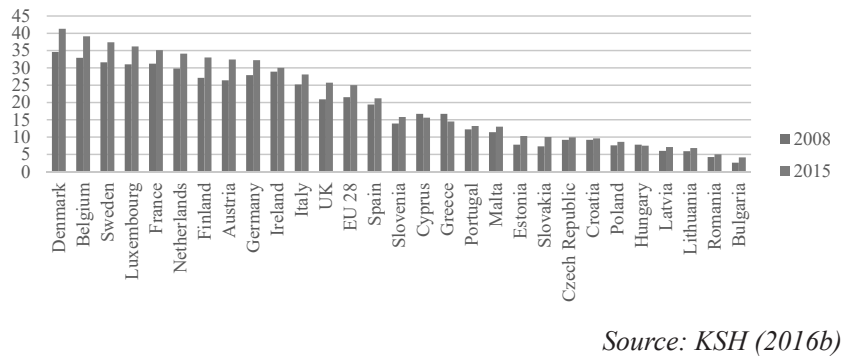

In Slovakia and the Czech Republic automotive sales constitute a significant proportion of exports and the industry has similar effects on the whole economy (EY, 2013a; EY, 2013b). Slovakia has the highest per capita car production in the world and it is the third-largest car producer among the new EU members after the Czech Republic and Poland (EY, 2013b).

In Hungary, due to the advanced level of technologies, wide range of automation, high level of work organization and product range, the automotive sector has the highest production value per employee within the machinery industry and plays a key role in the employment. With company establishments, production capacity expenditures and widening supplier networks, the industry has generated a growing demand for labor and has contributed to the declining unemployment rate of the region. These large, export-oriented com-

Table 2

\section{Changes in employment rates (within population between 15-64 ages)}

\begin{tabular}{|c|c|c|c|c|c|c|}
\hline \multirow[b]{2}{*}{ Reglon } & \multicolumn{3}{|c|}{ Employment rate } & \multicolumn{3}{|c|}{ Unemployment rate } \\
\hline & 2010 & 2014 & 2015 & 2010 & 2014 & 2015 \\
\hline Central Hungary & 60.0 & 66.0 & 67.6 & 9.0 & 6.2 & 5.3 \\
\hline Central Transdanubia & 57.0 & 64.3 & 67.9 & 10.1 & 5.6 & 4.5 \\
\hline Western Transdanubia & 58.6 & 65.8 & 67.5 & 9.3 & 4.6 & 3.8 \\
\hline Southern Transdanubia & 52.4 & 58.6 & 60.2 & 12.5 & 7.9 & 8.2 \\
\hline Northern Hungary & 48.3 & 55.7 & 59.0 & 16.3 & 10.5 & 8.7 \\
\hline Northern Great Plain & 49.0 & 57.3 & 58.9 & 14.5 & 11.9 & 10.9 \\
\hline Southern Great Plain & 54.1 & 59.7 & 62.2 & 10.5 & 9.0 & 8.0 \\
\hline Hungary (total) & 54.9 & 61.8 & 63.9 & 11.3 & 7.8 & 6.8 \\
\hline
\end{tabular}

Source: $K S H(2016 a)$ 
panies have significant impact on the improvement of the trade balance (KSH, 2011). Local companies with successful transformation of the production structure together with newly-settled foreign firms have enabled the automotive industry to have outstanding value generating capabilities, first of all in the Western regions of Hungary (KSH, 2011).

In 2015, disparities in employment levels of the different Hungarian regions decreased slightly, employment rates increased and unemployment rates declined in all regions compared to the previous year (with the exception of the Southern Transdanubia region). While in Central Hungary and Central- and Western Transdanubia regions the labor indicators were favorable, in Southern Transdanubia, Northern Hungary, Northern- and Southern Great Plain they were far below the national average. The highest employment rates were in Central and Western Transdanubia (Table 2) $(\mathrm{KSH}$, 2016a).

Beside the sufficient pool of high-skill talent and cheap workforce, the North-West Hungarian region also has several research universities, e.g. Széchenyi István University in Győr, where a wide range of automotive training and education take place. The institution has developed strong and active cooperation with automotive enterprises of the region, like Audi (KSH, 2011).

Among the Hungarian processing industry, the weight of the vehicle production was more than $28.6 \%$ in 2015 , increased from a level of $18.5 \%$ in 2011 . In $2015,10.8 \%$ of processing industry's output came from computer, electronics and optical products manufacturing, which counts as the second largest industry in the country, followed by food, beverage and tobacco production with $10.3 \%$. The shares of the other sectors are insignificant (KSH, 2016b).

Automotive industry's average wages are high compared to the national economy average or to the industry average.

\section{Monthly gross average wages in the processing industry, 2015}

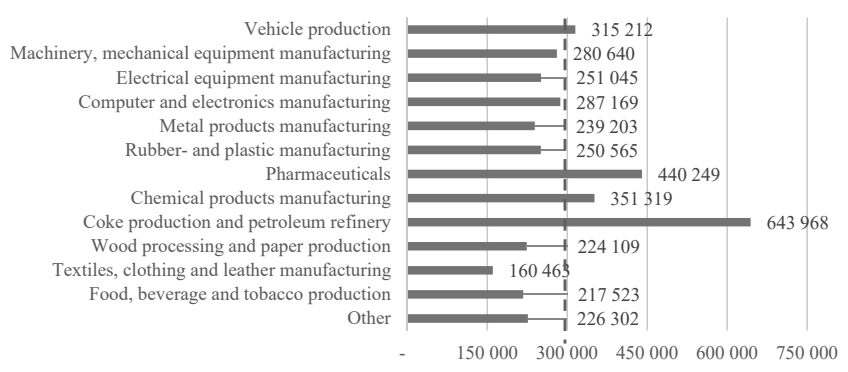

Source: $K S H(2016 b)$

Figure 5
As Figure 5 presents, gross average wages were above the industrial average (299,000 Forint) in four subsectors of the processing industry (vehicle production, pharmaceuticals, chemical products manufacturing and mining) with a range of 315,000 and 644,000 Forint. Since the proportion of graduated engineers is lower in the automotive industry, its average wages do not reach the level of the above-mentioned subsector. In other subsectors average wages were far below the industry average (between 160,000 and 287,000 Forint) (KSH, 2016b). According to KSH, the average wage in Hungary was net 159,000 Forint in June 2015. Average salary in the automotive industry is net 196,000, which is above the national average, but far below the German salaries in the same positions (KSH, 2016b).

For the Hungarian employers it was difficult to compete for engineers against the Western European companies, but according to a recent study conducted by the German Institutes for Economy (Institut der deutschen Wirtschaft Köln, IW), Germany's economy will need 100,000 electric engineers over the next ten years, thus the Hungarian brain drain is expected to increase (Institut der deutschen Wirtschaft Köln, 2016).

Several existing studies about electric devices show a similar pattern of specialization, when advanced economies are responsible for the contribution of skilled labor and capital while emerging economies deliver the low-skilled activities with little added value (Timmer et al., 2014). It is the case in the automotive industry in Hungary, as well. A significant share of intermediate production processes of German cars is performed outside of the country, typically in Europe and a huge part of German cars' value is produced abroad. In this regard, the question often arises: to what extent are these cars really German? (Gurgul - Lach, 2016).

\section{Domestic and export sales distribution in the processing industry, 2015}

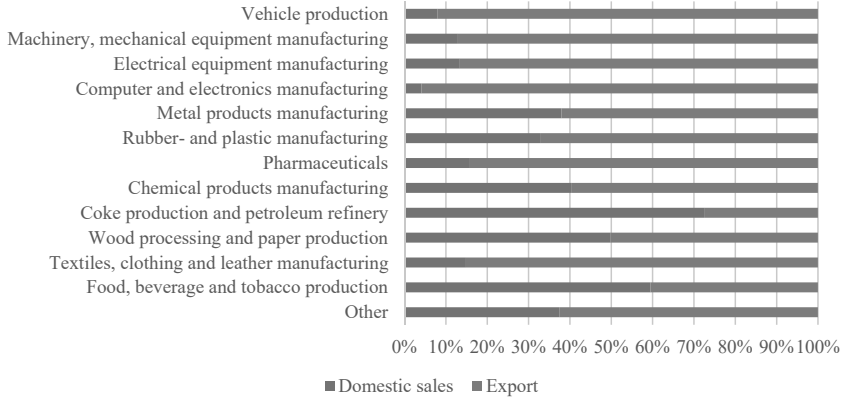

KSH (2016b)

The significant weight of physical working activities can hinder the upgrading process to the more value 
added segments of the supply chain (as higher value added activities like design, sales or R\&D are carried only to a limited extent in the country). According to Stocker (2014) an increase in the GVC participation of the local suppliers could have a positive effect on the value added per revenue. As Figure 6 shows, more than $90 \%$ of the automotive industry's production is exported to countries abroad. However, a large amount of raw materials and production lines are imports, therefore the value added in Hungary is relatively small $(\mathrm{KSH}$, 2016b).

Despite having a positive influence in general (see Figure 7 for the dominant role of the subsector), the national economy's exposure to the automotive industry and to its key players' decision making is dangerously high. In Hungary's GDP the automotive role is not extreme high, it has around $4.5 \%$ share, but the industry has a domestic value added of 39\% (KSH, 2016b). Even though the number of small and medium enterprises in Hungary is large, they realize only a fairly limited part of the industrial production. It is especially characteristic of the automotive industry, where there are ca. 900 companies, that only about 70 companies have more than 250 employees to produce the $90 \%$ of the sector's output. Small players are stronger in the domestic sales, not in export activities (KSH, 2016b).

\section{Annual production values in the processing industry (billion HUF), 2015}

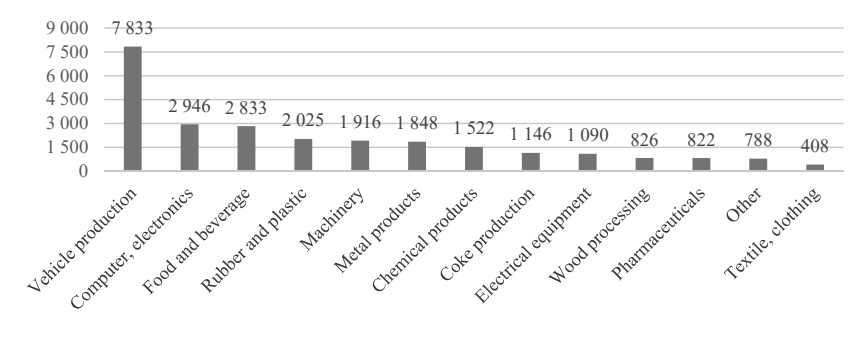

Source: KSH (2016b)

As Table 3 in the appendix shows, 17 foreign-owned automotive industry players are among the top 50 biggest exporter companies in Hungary. Aggregate production value of the three major car manufacturers (Audi, Mercedes and Suzuki) is greater than the rest of the automotive industry (components manufacturers) (HVG, 2016).

\section{Future of the automotive industry in Hungary and some threats}

Electrical cars are spreading globally with new technological basis and they are expected to account for a sig- nificant share of the global car sales within the next ten years (PWC, 2014b). This process could be further fueled by political ambitions, which would relegate diesel vehicles from bigger cities until 2030. The replacement of the internal combustion engines by electro motors can result in a situation where large automotive manufacturers lose their competitive advantage within a short time. As the car industry has a dominant role in Hungary, the electric car revolution in the next decades can particularly affect the country. The domestic motor and automotive manufacturers and a significant part of the suppliers produce internal combustion vehicles and parts. They should be prepared to be able to serve markets in the future as well, otherwise the demand for their products - which counts today as the $18-20 \%$ of the total export (KSH, 2017) - will be significantly diminished. According to the KSH, not just complete vehicles but bodyworks, motors and their components are also sold abroad in a significant amount. It is a very important aspect, because there is a huge difference between the electro cars and the traditional cars, namely the electro cars have a way less and totally different components compared to the traditional ones. With the penetration of the electro car manufacturing, the domestic manufacturers should change their production processes, otherwise their output will be obsolete in the future. It will be a long process, and there are signs from the automotive manufacturers in Hungary, especially from Audi and Mercedes that they aware of the challenges they face. As an example Mercedes' newest factory in Kecskemét, planned to start operating at the end of the decade, will also produce alternative-powered models. We can assume that Mercedes will produce complete electro cars in Hungary in the near future (Mercedes-Benz, 2016). In case of Audi, the company plans the serial production of electro cars and electro motors in the Hungarian plant starting from the years 2018-2019, stated Peter Kössler, President of Audi Hungaria Motor Ltd. (Audi Hungaria Kft., 2016). In case of Suzuki, the hybrid version of the new Baleno and Ignis models are planned to be produced in Esztergom (Magyar Suzuki Zrt., 2016).

\section{Conclusion}

Companies from advanced economies have chosen other countries with lower wages for their unskilled-labor-intensive production activities and have left the high value added functions and strategic operations at home, where the necessary skilled workers have been available (Timmer et al., 2014). "GVCs today are complex networks of pre-production, production, trade and consumption." (Law, 2016). The embeddedness in GVCs are determined by the local economic, social 
and institutional conditions. The availability of inputs like labor, infrastructure, capital and other resources are important economic factors; the accessibility of skilled labor and education are main social elements, while tax policies, labor regulations, subsidies are relevant institutional features. According to Gereffi and Fernandez-Stark (2016), economic upgrading means that companies, countries or regions move to activities with higher values in GVCs to increase their benefits. These benefits of the global participation can be higher value added, security, profit or capabilities. To be able to move up the value chain in knowledge-intensive manufacturing and services, CEE economies need to invest in R\&D and innovation. Local workforce should be qualified enough to be able to enter GVCs. The education system allows countries to have a well-educated population, which is able to serve knowledge-intensive industries, but building up clusters and collaboration between companies, research institutions and universities is required. Furthermore, a modern and effective infrastructure is also a key element of growth and GVC participation of companies (OECD, 2014).

These GVC requirements are also valid in the case of Hungary: from 2011 the vehicle and vehicle parts production became the number one engine of the industrial production. With a share of $20 \%$ it counts as one of the largest sub-sectors in the processing manufacturing ahead of computer, electronic and optical products. The sector's share reached $30 \%$ in 2015 (KSH, 2016b). Beside the large motor and vehicle manufacturers, there is a strong network of automotive suppliers operating in the country. More than 700 companies are present in the sector as a supplier (PWC, 2014a). The presence of the multinational automotive manufacturers improves the quality and skills of the workforce and education in the country. Moreover, it has economic prospering effects (GDP growth, increasing wages, etc.) and improving effects on the general company culture due to partnerships with local suppliers (managerial skills, organizational methods, etc.). However, the extent of the value added part in the export volume is relatively small, because the share of imported parts for the production is large. Furthermore, foreign companies are influenced strongly by the Western European headquarters and some car brands' success may have too much influence on the performance of the whole economy.

In general, with the spread of different automation technologies, the functional upgrading process is observable from the labor-intensive to capital-intensive processes (Contreras et al., 2010). Nowadays' electric car revolution can particularly affect Hungary. Electrical cars are expected to account for a significant share of the global car sales within the next ten years, while all the Hungarian motorcycle and car manufacturers and a significant portion of the suppliers produce internal combustion vehicles and components. The large manufacturers in Hungary, especially Audi and Mercedes have shown some evidence of development in this direction, which can result in the production of electric cars, motors, batteries and other components in Hungary in future. To ensure growth, the country needs to invest in education and training of workers and so to raise labor productivity. If CEE governments would like to prevent their economies from being locked into a low-wage, low-tech, low value added development stage, they need to provide funds for education and training and invest in R\&D (Havas, 1997). Moreover, high-level cooperation is required between companies, universities and research institutes to establish an attractive atmosphere (PWC, 2014a). Last years' investments show some good initiatives in R\&D activities in Hungary, but there is still room to be more attractive to high value added activities.

\section{References}

Aghion, P. - Howitt, P. - Mayer-Foulkes, D. (2005): The Effect of Financial Development on Convergence: Theory and Evidence. The Quarterly Journal of Economics, 120(1), p. 173-176.

Alvstam, C. G. - Ivarsson, I. - Petersen, B. (2016): Are Multinationals From

Emerging Economies Configuring Global Value Chains in New Ways? EIBA Conference, Vienna, December 2-4, 2016, Conference contribution 2016, p. 1-37.

Audi Hungaria Kft. (2016): Webpage: The Company - The Story of Audi Hungaria https://audi.hu/en/ the-company/the-story-of-audi-hungaria/

Balaton, Károly (2005): Attitude of Hungarian companies towards challenges created by EU-accession, Journal for East-European Management Studies, Vol. 10, Iss. 3, p. 247-258.

Balaton, Károly (2011): What lessons can we learn from the present economic crisis for the possible future strategies of enterprises - Lessons from Hungary and Slovakia, International Academy of Business and Public Administration Disciplines Dallas, Texas, April 7-11, 2011, p. 1-3.

Balaton, K. - Hortoványi, L. - Incze, E. - Laczkó, M. - Szabó, Zs. - Tari, E. (2014): Stratégiai menedzsment. Budapest: Akadémiai Kiadó

Balaton, Károly - Tari, Ernö (szerk.) (2014): Stratégiai és üzleti tervezés. Budapest: Akadémiai Kiadó

Baldwin, R. (2006): Globalization: The Great Unbundling(s), Prime Minister's Office. Economic Council of Finland, Helsinki, September 20, 2006, p. 5-8., 46. 
Baldwin, R. (2009): Integration of the North American Economy and Newparadigm Globalization. Graduate Institute, Geneva, p. 52., 57.

Baldwin, R. - Ito, T. - Sato, H. (2014): The Smile Curve: Evolving Sources of Value Added in Manufacturing, March 2014, p. 1-3.

Bamber, P. - Fernandez-Stark, K. - Gereffi, G. - Giunn, A. (2013): Connecting Local

Procedures in Developing Countries to Regional and Global Value Chains - Update. OECD Trade Policy Paper, No. 160, December 2013, p. 5., 21., 36.

Beleska-Spasova, E. (2016): Coupling Versus Decoupling of the GVC: What creates firm competitive advantage. Henley Business School, University of Reading EIBA Conference Vienna, 2016 December, p. 1-16.

Blomström, M. - Kokko, A. (2003): The Economics of Foreign Direct Investment Incentives. Working Paper 9489, National Bureau of Economic Research 1050 Massachusetts Avenue Cambridge, MA 02138, February 2003, p. 3., 8-9., 12-14.

Cattaneo, O. - Gereffi, G. - Staritz, C. (2010): Global Value Chains in a Postcrisis World - A development perspective. The World Bank, p. 211.

Contreras, O. F. - Carillo, J. - Estrada, J. A. (2010): The Creation of Local Suppliers Within Global Production Networks: The Case of the Ford Motor Company in Hermosillo, Mexico. p. 23-39.

European Central Bank (ECB) (2009): FDI and Productivity Convergence in Central and

Eastern Europe: An industry level investigation. by Bijsterbosch, Martin and Kolasa, Marcin, Working Paper Series, No 992, January 2009, p. 5-15.

EY (2013a): The Central and Eastern European Automotive Market: Czech Republic. http://www.ey.com/ $\mathrm{gl} / \mathrm{en} /$ industries/automotive/the-central-and-eastern-european-automotive-market---country-profile--czech-republic

EY (2013b): The Central and Eastern European Automotive Market: Slovakia. http://www.ey.com/gl/en/ industries/automotive/the-central-and-eastern-european-automotive-market---country-profile--slovakia

Fernandez-Stark, K. - Frederick, S. - Gereffi, G. (2011): The Apparel Global Value Chain. Duke Center on Globalization, Governance and Competitiveness, November 2011, p. 13., 51-54.

Francois, J. - Wörz, J. (2007): Producer Services, Manufacturing Linkages and Trade. Tinbergen Institute Discussion Paper, June 2007, p. 7-8.

Gereffi, G. - Korzeniewicz, M. - Korzeniewicz, R. P. (1994): Commodity Chains and Global Capitalism: Introduction: Global Commodity Chains. Westport, Connecticut, London, p. 2.
Gereffi, G. (2005): The Global Economy: Organization, Governance, and Development. in: N.J. Smelser - R. Swedberg (eds): The Handbook of Economic Sociology. Princeton: Princeton University Press, p. 160-182.

Gereffi, G. - Fernandez-Stark, K. (2016): Global Value Chain Analysis: A Primer. Duke Center on Globalization, Governance and Competitiveness, July 2016, p. 10-14., 22-24., 32.

Gereffi, G. (2016): Global Value Chains and Upgrading: Export Promotion in FTZs. Bulletin, World Free Zones Organization, Issue 05, March 2016, p. 3-11.

Grodzicky, M. J. (2014): Global Value Chain and Competitiveness of V4 Economies. Jagiellonian University, Institute of Economics and Management, p. 13-31.

Gurgul, H. - Lach, L. (2016): Comparative Advantage of the EU in Global Value Chains: How important and efficient are new EU members in transition? Managerial Economics, 2016 vol. 17. No. 1, p. 2158.

Havas, Attila (1997): Foreign Direct Investment and Intra-Industry Trade: The Case of the Automotive Industry in Central Europe. in: D. Dyker (ed.) (1997): The Technology of Transition: Science and Technology for Transition Countries. Budapest: Central European University Press, p. 211-240.

Humphrey, J. - Schmitz, H. (2002): How Does Insertion in Global Value Chains Affect Upgrading in Industrial Clusters? Regional Studies, Institute of Development Studies, University of Sussex, Brighton, p. 1-16.

Humphrey, J. - Memedovic, O. (2003): The Global Automotive Industry Value Chain: What Prospects for Upgrading by Developing Countries. United Nations Industrial Development Organization, Vienna, 2003, p. 2.

HVG (2016): Top 50: HVG-toplista a legnagyobb magyar cégekröl. Muck Tibor http://hvg.hu/enesacegem/20160724_Top_50_HVGtoplista_a_legnagyobb_magyar_cegekrol

Institut der deutschen Wirtschaft Köln (2016): Erwerbstätigkeit von E-Technik-

Ingenieuren im Spiegel des Mikrozensus. Dr. Oliver Koppel, Köln, August 2016, p. 9-10.

https://www.iwkoeln.de/_storage/asset/301069/storage/ master/file/10368229/download/Gutachten_2016_ Arbeitsmarkt_E-Technik-Ingenieure.pdf

KSH - Központi Statisztikai Hivatal (2011): A járműipar szerepe és helyzete a Nyugat-Dunántúlon. 2011/05, p. 1-51.

KSH - Központi Statisztikai Hivatal (2016a): Magyarország, 2015, ISSN: 1416-2768, p. 35. 
KSH - Központi Statisztikai Hivatal (2016b): Jelentés az ipar 2015. évi teljesítményéről https://www.ksh. hu/docs/hun/xftp/idoszaki/jelipar/jelipar15.pdf

KSH - Központi Statisztikai Hivatal (2017): A külkereskedelmi termékforgalom áruszerkezete forintban. 2016, https:/www.ksh.hu/docs/hun/xstadat/xstadat eves/i qkt022.html

Low, Patrick (2016): Free Zones in a World of Global Value Chains. Bulletin, World Free Zones Organization, Issue 05, March 2016, p. 12-17.

Magyar Suzuki Zrt. (2016): 25' - Company Introductory Material http://www.suzuki.hu/marine/files/document/document/155/suzuki_cegismerteto_2016. pdf

McKinsey Global Institute (Eric Labaye, Pal Erik Sjåtil, Wojtek Bogdan, Jurica Novak, Jan Mischke, Mladen Fruk, Oana Ionutiu) (2013): A new dawn, Reignity growth in Central and Eastern Europe. December 2013, p. 29-114.

Mercedes-Benz Manufacturing Hungary Kft. (2016): Webpage: The Story of the Plant - Milestones, Facts and Data.http:/gyar.mercedes-benz.hu/rolunk/gyartotenet/tenyek-es-adatok

OECD (2014): Global Value Chains: Challenges, Opportunities, and implications for policy

OECD, WTO and World Bank Group. Report prepared for submission to the G20 Trade Ministers Meeting, Sydney, Australia, 19 July 2014, p. 1-53.
OECD/WTO (2011): Aid for Trade 2011: Results Emerging from the Case Stories World Trade Organization and OECD, p. 1-65.

$P W C$ (2014a): Leading sector in Hungary: Automotive. http://www.pwc.com/hu/en/publications/investing-in-hungary/leading_sector_automotive.html

$P W C$ (2014b): Merre tart az elektromos autók piaca? - A plug-in elektromos és a tisztán elektromos gépjármúvek jövője Magyarországon. https://www. pwc.com/hu/hu/kiadvanyok/assets/pdf/merre_tart az_elektromos_autok_piaca-e-car_2014.pdf

Staritz, C. - Gereffi, G. - Cattaneo, O. (2011): Special Issues on Shifting End Markets and Upgrading Prospects in Global Value Chains. International Journal of Technological Learning, Innovation and Dev., 2011 Vol 4, No 1/2/3, p. 1-12.

Stocker, Miklós (2014): Business Performance of Hungarian Exporting Companies. in: Competitiveness of the CEE Region in the Global Economy. First AIB-CEE Chapter Conference, Budapest, 2014.10.10, p. 8.

Timmer, M. P. - Erumban, A. A. - Los, B. - Stehrer, R. - J. de Vries, G. (2014): Slicing Up Global Value Chains, Journal of Economic Perspectives, Volume 28, Number 2, spring, p. 99-118.

World Economic Forum (WEF) (2012): The Shifting Geography of Global Value Chains: Implications for Developing Countries and Trade Policy. p. 8., 18-22. 


\section{Appendix}

The 50 largest export-revenue companies operating in Hungary, 2015

\begin{tabular}{|c|c|c|c|}
\hline Rank & Company name & Sector & Foreign sales rev. (mHUF) \\
\hline 1 & GE Infrastructure CEE Holding Ltd. & property management & 4483809 \\
\hline 2 & MOL PLC. & energy industry & 2998282 \\
\hline 3 & Audi Hungaria Motor Ltd. & car manufacturing & 2599054 \\
\hline 4 & Mercedes-Benz Manufacturing Hungary Ltd. & car manufacturing & 1062038 \\
\hline 5 & Samsung Electronics Hungarian PLC. & electronic industry & 627977 \\
\hline 6 & Hungarian Suzuki PLC. & car manufacturing & 580646 \\
\hline 7 & Wizz Air Hungary Ltd. & transportation & 493292 \\
\hline 8 & Felxtronics International Ltd. & electronic industry & 469051 \\
\hline 9 & MVM Hungarian Electrical Works PLC. & property management & 463962 \\
\hline 10 & Robert Bosch Electronics Ltd. & car parts manufacturing & 458569 \\
\hline 11 & Bimbo Hungria PLC. & wholesale trade & 451934 \\
\hline 12 & Richter Gedeon Chemical Factory PLC. & pharmaceutical industry & 330244 \\
\hline 13 & PCE Paragon Solutions Ltd. & electronic industry & 284648 \\
\hline 14 & BorsodChem PLC. & chemical industry & 284470 \\
\hline 15 & GDF Suez Natural Gas Trading Ltd. & energy trade & 257787 \\
\hline 16 & Robert Bosch Energy and Body System Ltd. & car parts manufacturing & 275455 \\
\hline 17 & Sanofi-aventis/Chinoin & pharmaceutical industry & 261486 \\
\hline 18 & Harman Becker Ltd. & car parts manufacturing & 260113 \\
\hline 19 & Jabil Circuit Hungary Ltd. & electronic industry & 232337 \\
\hline 20 & Electrolux Lehel Refrigerator Factory Ltd. & machine manufactures & 230081 \\
\hline 21 & MOL Petrolchemical PLC. & chemical industry & 225028 \\
\hline 22 & LuK Savaria Kuplunggyártó Ltd. & car parts manufacturing & 222382 \\
\hline 23 & ContinentalAutomotive Hungary Ltd. & car parts manufacturing & 219915 \\
\hline 24 & Michelin Hungary Ltd. & rubber manufacturing & 218975 \\
\hline 25 & Hankook Tire Hungary Ltd. & rubber manufacturing & 211968 \\
\hline 26 & Alcoa-Köfém Ltd. & metal processing & 204798 \\
\hline 27 & Delphi Hungary Ltd. & car parts manufacturing & 193434 \\
\hline 28 & Teva Pharmaceutical Works PLC. & pharmaceutical industry & 185192 \\
\hline 29 & Lear Corporation Hungary Ltd. & car parts manufacturing & 180317 \\
\hline 30 & Denso Manufacturer Hungary Ltd. & car parts manufacturing & 178704 \\
\hline 31 & NI Hungary Ltd. & electronic industry & 168643 \\
\hline 32 & SE-CEE Schneider Electric Ltd. & wholesale trade & 162986 \\
\hline 33 & Opel Southeast Europe Ltd. & car trade & 148990 \\
\hline 34 & BorgWagner Oroszlány Ltd. & car parts manufacturing & 139253 \\
\hline 35 & Synopsys Global Ltd. & business services & 113653 \\
\hline 36 & Glencore Grain Hungary Ltd. & wholesale trade & 108444 \\
\hline 37 & Valeo Auto-Electric Hungary Ltd. & car parts manufacturing & 107571 \\
\hline 38 & Johnson Controls Mór LP. & car parts manufacturing & 107046 \\
\hline 39 & Porsche Hungaria Ltd. & car trade & 102147 \\
\hline 40 & SMR Automotive Mirror Technology LP. & car parts manufacturing & 100054 \\
\hline 41 & Robert Bosch Automotive Steering Ltd. & car parts manufacturing & 97382 \\
\hline 42 & Ibiden Hungary Ltd. & car parts manufacturing & 97259 \\
\hline 43 & Egis Pharmaceutical Works PLC. & pharmaceutical industry & 97150 \\
\hline 44 & Videoton Holding PLC. & electronic industry & 97120 \\
\hline 45 & Hungarian Telecom Telecommunicatio PLC. & telecommunication & 89758 \\
\hline 46 & Apcom CE Ltd. & wholesale trade & 89215 \\
\hline 47 & Coloplast Hungary Ltd. & plastic industry & 85417 \\
\hline 48 & Grundfos Hungary Ltd. & machine manufactures & 83242 \\
\hline 49 & Bunge Vegetable Oil Industry PLC. & food industry & 83205 \\
\hline 50 & Zollner Ltd. & electronic industry & 81678 \\
\hline
\end{tabular}

